\title{
Correction to: Impact of Scribe Experience on Undergraduate Medical Education
}

William H. Hewlett ${ }^{1}$ (D) $\cdot$ Christopher M. Woleben ${ }^{1} \cdot$ Jacob Alford $^{1} \cdot$ Sally A. Santen ${ }^{1} \cdot$ Peter Buckley $^{1} \cdot$ Moshe Feldman $^{1}$

Published online: 23 September 2020

(C) International Association of Medical Science Educators 2020

\section{Correction to: Medical Science Educator} https://doi.org/10.1007/s40670-020-01055-3

The original article was updated to include the author Peter Buckley in the author list.

Publisher's Note Springer Nature remains neutral with regard to jurisdictional claims in published maps and institutional affiliations.

The online version of the original article can be found at https://doi.org/ 10.1007/s40670-020-01055-3

William H. Hewlett

hewlettwh@vcu.edu

1 Virginia Commonwealth University School of Medicine,

Richmond, VA, USA 